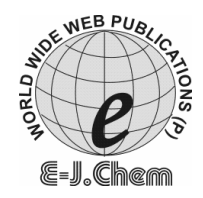

http://www.e-journals.net
ISSN: 0973-4945; CODEN ECJHAO

E-Journal of Chemistry

2010, 7(2), 526-530

\title{
Determination of Heavy Metals in Crab and Prawn in Ojo Rivers Lagos, Nigeria
}

\author{
R. A. OLOWU ${ }^{\# *}$, O. O. AYEJUYO, A. ADEJOROI ${ }^{\S}$, G. O. ADEWUYI ${ }^{\S}$, \\ M. O. OSUNDIYA ${ }^{\#}$, C.T. ONWORDI ${ }^{\#}$, K A. YUSUF and M.S. OWOLABI \\ \#Department of Chemistry, \\ Lagos State University (LASU), PMB 1087 Apapa, Lagos, Nigeria. \\ ${ }^{\S}$ Department of Chemistry, University of Ibadan, Ibadan, Nigeria. \\ Department of Chemistry, University of Lagos, Lagos, Nigeria. \\ rolowu@uwc.ac.za
}

Received 19 August 2009; Accepted 10 October 2009

\begin{abstract}
The level of heavy metals in crabs and prawns was investigated using Atomic Absorption Spectrophotometer. The mean concentration of copper in the crab was $1.56 \pm 0.87 \mu \mathrm{g} / \mathrm{g}$; the mean concentration of zinc in the crab was also $0.64 \pm 1.96 \mu \mathrm{g} / \mathrm{g}$. Chromium had the highest mean concentration of $8.936 \pm 35.4 \mu \mathrm{g} / \mathrm{g}$ while cadmium had the lowest mean of $1.66 \pm 1.82 \mu \mathrm{g} / \mathrm{g}$ lead was not detected. The mean concentration of heavy metals in prawn samples were follows: copper: $1.04 \pm 0.6 \mu \mathrm{g} / \mathrm{g}$, cadmium: $0.07 \pm 0.08 \mu \mathrm{g} / \mathrm{g}$, chromium: $4.06 \pm 7.00 \mu \mathrm{g} / \mathrm{g}$ and $\mathrm{Zn} 0.64 \pm 0.45 \mu \mathrm{g} / \mathrm{g}$. Lead was not detected in prawn. The mean concentration of copper, cadmium and zinc in prawn was observed to be within the range NAFDAC standard for water and aquatic foods while crabs have higher mean concentration of heavy metals with the exception of zinc and copper are within the limit.
\end{abstract}

Keyword: Bioaccumulation, Organ chlorine, Heavy metal, Ecosystem.

\section{Introduction}

Aquatic animals include fishes, crabs, prawns etc. have their own way of life which make it possible for them to live in water. For instance their way of feeding, swimming and reproduction is known as adaptation. Some animals have streamlined bodies so as to swim well, others have very light weight for the same swimming purpose ${ }^{1}$.

Several researches revealed heavy metal content in crustacean. The source of the heavy metals in them, and the toxic effect of the heavy content in crustaceans and the effects on man who in turn consume the crustacean ${ }^{1}$. Although many heavy metals are essential for animal tissues metabolism, the ranges between beneficial and toxic levels are very small. There is an increasing concern about the health effect in human due to continuous consumption of food contaminated with heavy metals and the extent of this contamination depends on several complex factors, one of which is the specific metabolic and homeostatic mechanisms operating 
in the type of food and tissue considered ${ }^{2}$. Heavy metals are introduced in an aquatic environment through domestic and industrial waste discharge into water body. It is rather of great concern that over $80 \%$ of the industries in the country discharge their solid waste, liquid and gaseous effluent containing toxic concentration of heavy metal such as cadmium, lead, copper, zinc and nickel into the environment without any prior treatment while just only $18 \%$ of undertake rudimentary recycling prior to disposal ${ }^{3-5}$. Agricultural activities also contributed to the pollution or the aquatic environment through run off which find their ways into the water bodies ${ }^{11}$.

One of the most similar and most recent researches found was the one that investigated the effect of the heavy metals lead $(\mathrm{Pb})$ and zinc $(\mathrm{Zn})$, individually and in combination i.e three metal solution on both the brood and larval development of the burrowing crustacean (prawn). Effects of industrialization, intensive agriculture and coastal engineering (including tourism) have seriously threatened marine life. The problem is further extrapolated in the sense that, rivers carry their pollutant to estuaries and finally to coastal oceans, where harmful substances enter into the food chain and become bioaccumulated in fish and other edible organisms, particularly in near shore ${ }^{6-8}$.

Many substances pollute the marine environment, but non biodegradable compounds are the most dangerous due to their innate ability to constantly remain with the ecosystem. Heavy metals are known for their high toxicity, as are organo chlorine compounds such as pesticide and PCB (s) among others, metal pollutants are currently considered to be some of the most toxic, persistent and widespread contaminants in estuarine systems in the sense that dissolved or suspended metals become available to plankton, nekton and benthic filter and deposit feeders ${ }^{6,9,10}$.

The factors which contribute principally to the damaging effect of metal as environmental pollutants are, firstly, their inadequate biological degradation to inert metals and secondly, the trend of metals to accumulate and largely remain in the aquatic environment $^{6,11}$. Sediments have been reported to form the major repository of heavy metals in aquatic system while both allochthonous and autochtonous influences could make concentration of heavy metals in the water high enough to be of ecological significance ${ }^{11-13}$.

Metal pollution has become a major international issue since the 1960(s) when thousands of people were poisoned in Minamaten, Japan after consuming mercury-polluted sea foods. Some researchers affirmed main sources of metal pollution are domestic/industrial sewage, industrial effluents, oil and chemical spills, combustion emission, mining operations, metallurgical activities and non hazardous landfill sites ${ }^{16,7,4} . \mathrm{Pb}$ enters the aquatic environment through erosion and leaching from the soil, $\mathrm{Pb}$-dust fallouts from the atmosphere, combustion of petrol, domestic and industrial waste discharges, runoff of fallout deposits from roads and other surface as well as precipitation ${ }^{1,12}$.

Increasing concentrations of the metals $\mathrm{Pb}$ and $\mathrm{Zn}$ cause significant increases in the mortality in crabs and prawns. Increasing $\mathrm{Pb}$ and $\mathrm{Zn}$ concentrations in permutation with varying salinities exhibit a significant negative influence on crustacean development ${ }^{12}$.

The aim of this work is therefore to determine the heavy metals concentration in two marine organism (crab and prawn) in Ojo river so as to compare the level of heavy metals in crab and prawn with the consumable standard with a view of determining their suitability for human consumption.

\section{Experimental}

Sampling was carried out in accordance with the recommendation of UNEP reference method for marine pollution studies ${ }^{11}$. The sample of crab and prawn were collected from Ojo river. Prawn and crab were collected weekly for a period of six weeks using fishing drag net. 
Each prawn and crab was properly cleaned by rinsing with distilled water to remove debris, planktons and other external adherent. It was then drained under folds of filter, weighed, wrapped in aluminum foil and then frozen at $10{ }^{\circ} \mathrm{C}$ prior to analysis.

For analysis, the crab and prawn sample were defrosted for $2 \mathrm{~h}$, it was then weighed into a pre weighed petri-dish, and then dried at $80{ }^{\circ} \mathrm{C}$ in Gallenkamp hot box oven. The dried samples weight were taken and recorded at intervals of $4 \mathrm{~h}$ until a constant weight was obtained.

The dried samples of crab and prawn were put in a cleaned dried mortar separately and were grounded to fine particles and then sieve using a sieve of particle size $0.02 \mathrm{~mm} .0 .5 \mathrm{~g}$ each of samples were measured into clean dried beaker $(100 \mathrm{~mL}), 5 \mathrm{~mL}$ of aqua regia $\mathrm{HCl}$ and $\mathrm{HNO}_{3}(3: 1)$ was then added to the sample for digestion. The samples were allowed to be evenly distributed in the acid by stirring with a glass rod and then the beaker was place on the heater. The digested sample was filtered into a graduating cylinder and the filtrate was made up to $50 \mathrm{~mL}$ using distilled water. 200 Perkin Elmer atomic absorption spectrophotometer model was used to analyse the concentration $(\mu \mathrm{g} / \mathrm{g})$ of heavy metals in the six different samples of crab and prawn

\section{Results and Discussion}

The concentrations of the heavy metals determined in the crab and prawn from Ojo river are indicated in Table $1 \& 2$ respectively. The comparison between the concentrations of crab and prawn collected from Ojo river at the same period are also indicated in Table 3. The data shown that for crab samples, chromium has the highest concentration, followed by cadmium, copper and zinc respectively.

Table 1. Concentration of heavy metal in six different samples of crab.

\begin{tabular}{cccccc}
\hline Samples & $\mathrm{Cu}, \mu \mathrm{g} / \mathrm{g}$ & $\mathrm{Cd}, \mu \mathrm{g} / \mathrm{g}$ & $\mathrm{Pb}, \mu \mathrm{g} / \mathrm{g}$ & $\mathrm{Cr}, \mu \mathrm{g} / \mathrm{g}$ & $\mathrm{Zn}, \mu \mathrm{g} / \mathrm{g}$ \\
\hline $\mathrm{C} 1$ & 1.057 & 2.250 & $\mathrm{ND}$ & 30.330 & 6.060 \\
$\mathrm{C} 2$ & 0.033 & 4.000 & $\mathrm{ND}$ & 0.031 & 0.024 \\
$\mathrm{C} 3$ & 2.750 & 0.084 & $\mathrm{ND}$ & 1.646 & 0.092 \\
$\mathrm{C} 4$ & 1.320 & 1.360 & $\mathrm{ND}$ & 9.148 & 0.189 \\
$\mathrm{C} 5$ & $\mathrm{ND}$ & 0.118 & $\mathrm{ND}$ & 11.956 & 2.024 \\
$\mathrm{C} 6$ & 2.644 & 2.070 & $\mathrm{ND}$ & 0.502 & 3.728 \\
Mean & $1.56 \pm 0.87$ & 1.660 & $\mathrm{ND}$ & 8.930 & 0.640 \\
\hline
\end{tabular}

ND: Not detected

Table 2. Concentration of heavy metal in six different samples of prawn.

\begin{tabular}{cccccc}
\hline Samples & $\mathrm{Cu}, \mu \mathrm{g} / \mathrm{g}$ & $\mathrm{Cd}, \mu \mathrm{g} / \mathrm{g}$ & $\mathrm{Pb}, \mu \mathrm{g} / \mathrm{g}$ & $\mathrm{Cr}, \mu \mathrm{g} / \mathrm{g}$ & $\mathrm{Zn}, \mu \mathrm{g} / \mathrm{g}$ \\
\hline P1 & 0.466 & 0.280 & $\mathrm{ND}$ & 11.328 & 0.016 \\
P2 & 0.020 & 0.013 & $\mathrm{ND}$ & 0.015 & 0.032 \\
P3 & 1.202 & 0.030 & $\mathrm{ND}$ & 1.614 & 1.840 \\
P4 & 0.460 & 0.084 & $\mathrm{ND}$ & 0.956 & 0.042 \\
P5 & 2.070 & 0.144 & $\mathrm{ND}$ & 5.231 & 0.956 \\
P6 & 2.070 & 0.144 & $\mathrm{ND}$ & 5.231 & 0.956 \\
Mean & $1.040 \pm 0.600$ & $0.070 \pm 0.080$ & $\mathrm{ND}$ & $4.060 \pm 7.000$ & $0.640 \pm 0.450$ \\
\hline
\end{tabular}

The same manner of accumulation in crab samples was observed in the prawn samples and lead was found to be absent in both the crabs and prawn samples as shown in Figures 1 $\& 2$ respectively. The absence of lead may be attributed to lack of industrial activities around the sample site ${ }^{4}$. 
Table 3. Comparison of heavy metals content of crab and prawn collected at same periods.

\begin{tabular}{cccccc}
\hline Samples & $\mathrm{Cu}, \mu \mathrm{g} / \mathrm{g}$ & $\mathrm{Cd}, \mu \mathrm{g} / \mathrm{g}$ & $\mathrm{Pb}, \mu \mathrm{g} / \mathrm{g}$ & $\mathrm{Cr}, \mu \mathrm{g} / \mathrm{g}$ & $\mathrm{Zn}, \mu \mathrm{g} / \mathrm{g}$ \\
\hline $\mathrm{C} 1$ & 1.057 & 2.250 & $\mathrm{ND}$ & 30.330 & 0.060 \\
$\mathrm{P} 1$ & 0.466 & 0.280 & $\mathrm{ND}$ & 11.328 & 0.016 \\
\hline $\mathrm{C} 2$ & 0.033 & 4.000 & $\mathrm{ND}$ & 0.031 & 0.024 \\
$\mathrm{P} 2$ & 0.020 & 0.013 & $\mathrm{ND}$ & 0.015 & 0.032 \\
\hline $\mathrm{C} 3$ & 2.750 & 0.084 & $\mathrm{ND}$ & 1.646 & 0.092 \\
$\mathrm{P} 3$ & 1.202 & 0.030 & $\mathrm{ND}$ & 1.614 & 1.840 \\
\hline $\mathrm{C} 4$ & 1.320 & 1.360 & $\mathrm{ND}$ & 9.148 & 0.189 \\
$\mathrm{P} 4$ & 0.460 & 0.084 & $\mathrm{ND}$ & 0.956 & 0.042 \\
\hline $\mathrm{C} 5$ & $\mathrm{ND}$ & 0.118 & $\mathrm{ND}$ & 11.956 & 2.024 \\
$\mathrm{P} 5$ & 2.075 & 0.144 & $\mathrm{ND}$ & 5.231 & 0.956 \\
\hline $\mathrm{C} 6$ & 2.644 & 2.070 & $\mathrm{ND}$ & 0.502 & 3.728 \\
$\mathrm{P} 6$ & 2.070 & 0.144 & $\mathrm{ND}$ & 5.231 & 0.956 \\
\hline
\end{tabular}

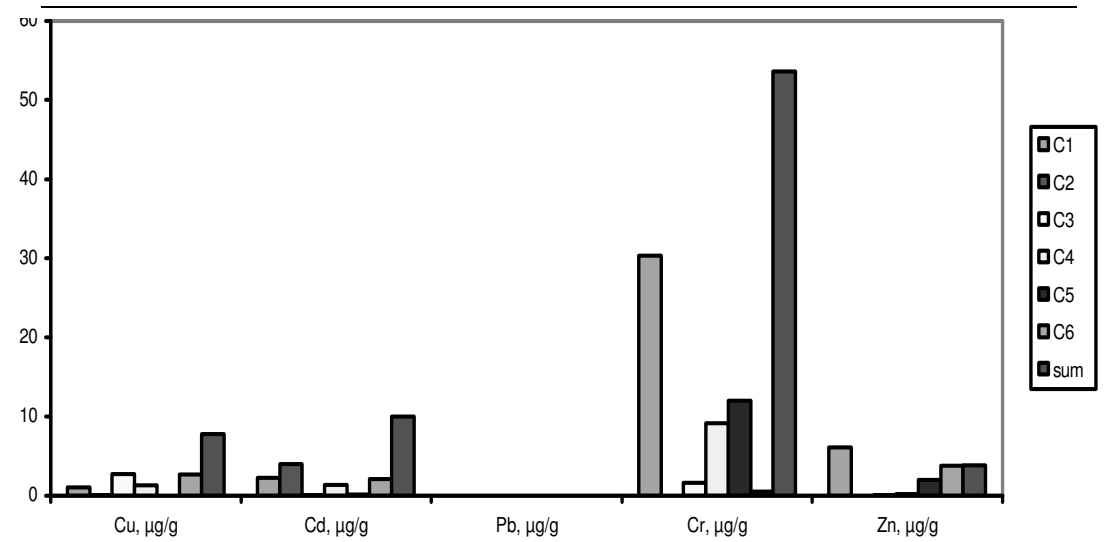

Figure 1. Concentration of heavy metals in crabs collected for a period of six weeks.

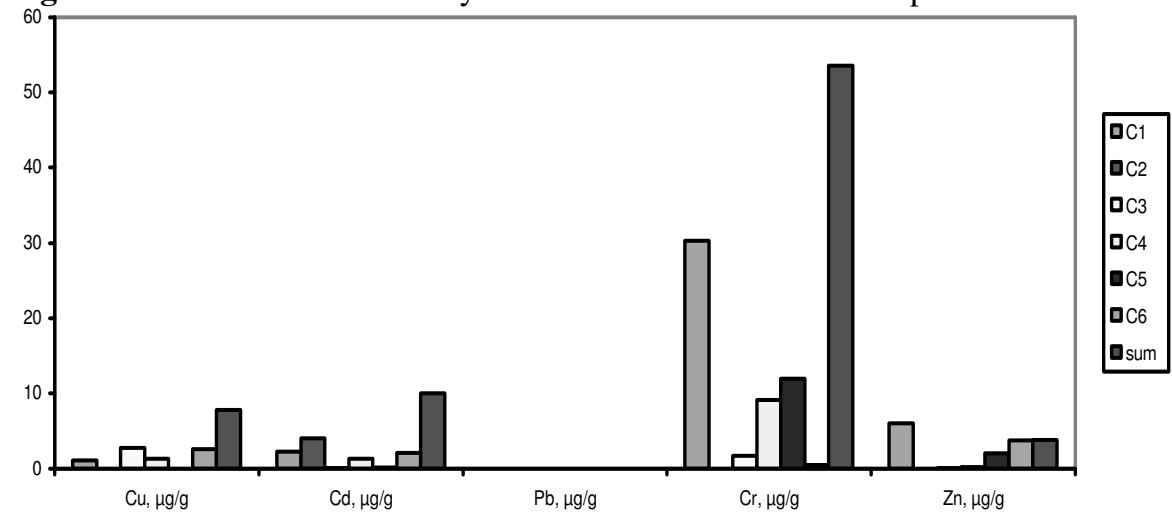

Figure 2. Concentration of heavy metals in prawns collected for a period of six weeks.

Metal accumulation levels in crabs were high in all cases compare to prawn except in lead which was not detectable in both samples. This observation may be due to the major functional differences in their body ${ }^{6,7}$. Similar comparison on heavy metal accumulation between $\mathrm{crabs}^{4}$ and fishes harvested in the same water system at same period has been reported $^{9,14,15}$. The variation is also an indication of the degree to which particular species 
pick up particulate matter from surrounding water and in particular sediments while feeding. Crabs are bottom feeder and are generally expected to concentrate more metals than surface feeders like prawn which is in agreement with earlier report ${ }^{13,14}$.

The absence of lead in the crab and prawn may be due to the activities around the location of the river. The area consist mainly farmland and few residential houses. There are few or no industrial activities around the location.

The mean concentration of copper cadmium and zinc in prawn is within the range of WHO and NAFDAC standards for water and aquatic foods while crabs have higher mean concentration of heavy metals above NAFDAC consumable standard for food with exception of zinc and copper which falls within the limits. Elevated concentration of copper as been reported to cause brain damage in mammals ${ }^{10}$.

\section{Conclusion}

From the result of the analysis it is concluded that the crabs from Ojo river accumulate more chromium and cadmium concentration above WHO and NAFDAC consumable standard for food which may cause inhibition of enzymes when consumed due to high concentration of cadmium $^{10}$ while prawn from the same river has its metal concentration within the WHO and NAFDAC standards for consumption. Cadmium has been reported to has no known function in biological systems and even small amounts can be toxic to organisms and its concentration in natural freshwater are typically around $0.01 \mu \mathrm{g} / \mathrm{L}^{16}$. From the analysis point of view prawns sampled from Ojo river in Lagos metropolis may be consider safe for consumption while the crab from the same river unsafe for consumption but the need for continuous monitoring to prevent bioaccumulation is necessary.

\section{References}

1. Baird D and Ulanowics R E, Mar Ecol Prog Ser., 1999,190, 211-222

2. Chukwujindu M A, Nwoso S O, Ossai E K and Nwajei G E, Am J Food Tech., 2008, 3(3), 220-223.

3. Odukoya O O and Ajayi S O, Nigeria J Nutritional Sci., 1987, 8(1), 41-49.

4. Jibiri N N and Adewuyi G O, Radioprotection, 2008, 43(2), 203-212.

5. Oyewo E O and Don-Pedro K N, West Afr J Appl Ecol., 2003, (4),115-123.

6. Shaw A W and Dahl R, Anal Chem Acta, 1999, 391(1), 35-37.

7 Charis K B and Abbasi S A Int J Environ Studies, 2005, 62, 137-145.

8. Adefemi S O, Asaolu S S and Olaofe O, Res J Environ Sci., 2008, 2(2), 151-155.

9 Koli A K, Williams W R, Mc Clarey E B, Wright E L and Burrell T M, Bull Environ Contam Toxicol., 1997, 17(1), 82-89.

10. Binning K and Baird, Water SA, 2001, 27(4), 461-466.

11. Ikem A, Egiebor N O and Nyavov K, Water, Air, Soil Pollut., 2003. 149, 51-57.

12. Adeniyi A A, Yusuf K A and Okedeyi O O, Environ Monit Assess., 2008, 137, 451-458.

13 Okoye B C O, Afolabi O A and Ajao E A, Int J Environ Studies, 1991, 37(1), 35-42.

14. Kakalu S E, Osibanjo O and Ajayi S O, Environ Int., 1987, 13, 247-251.

15. Williams A B, Ayejuyo O O and Adekoya.A, J Appl Sci., 2007, 7(13),1821-1823.

16. Lisa M S and Klaus N, Appl and Environ Microb., 2005, 71, 2484-2492.

17 Majolagbe A O and Bamgbose O, Chem Environ Res., 2007, 16 (1-2), 41-51. 


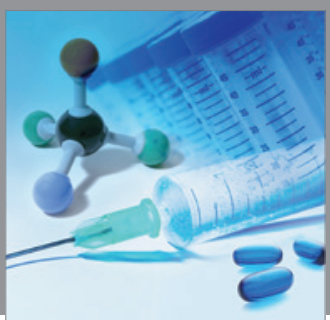

International Journal of

Medicinal Chemistry

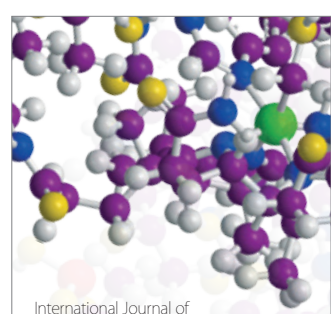

Carbohydrate Chemistry

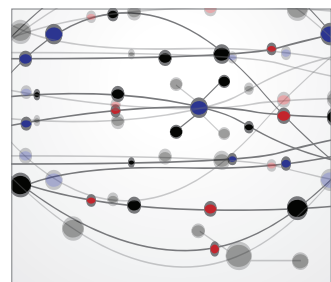

The Scientific World Journal
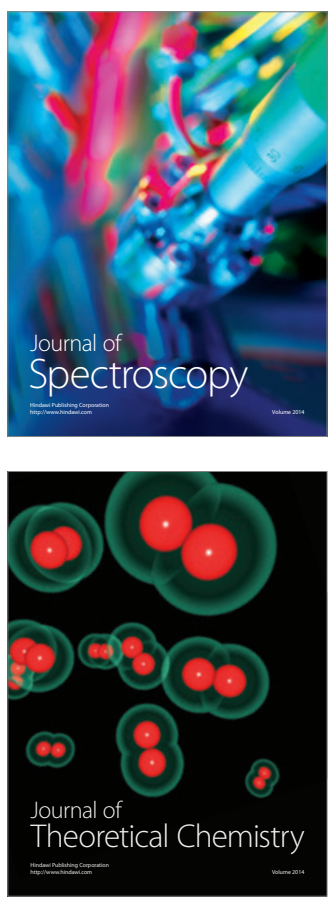
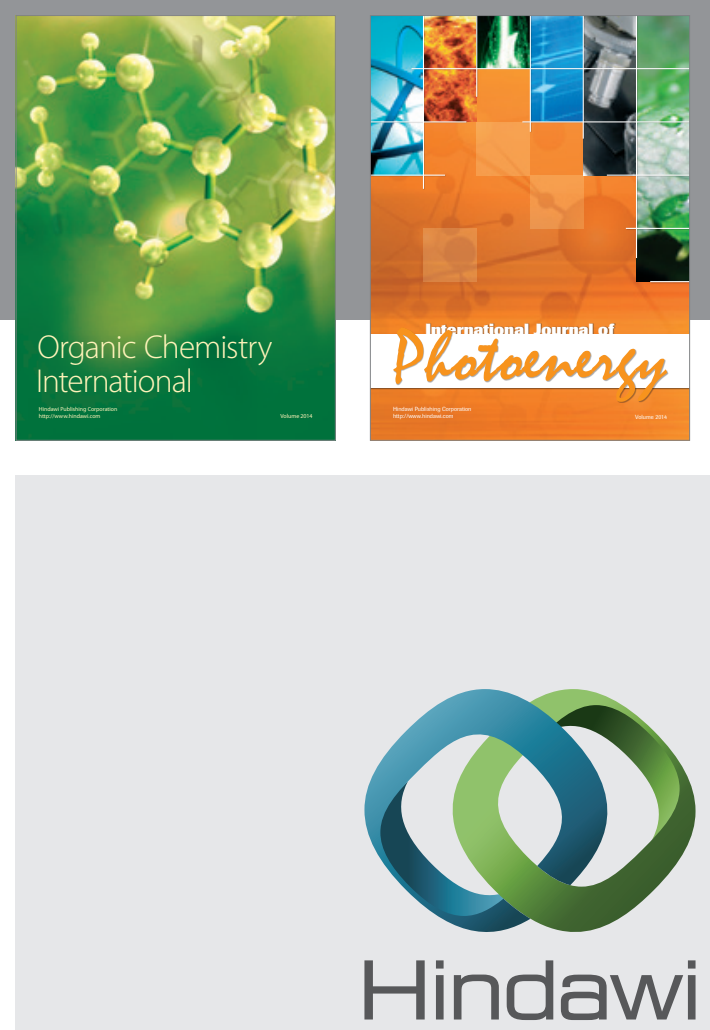

Submit your manuscripts at

http://www.hindawi.com
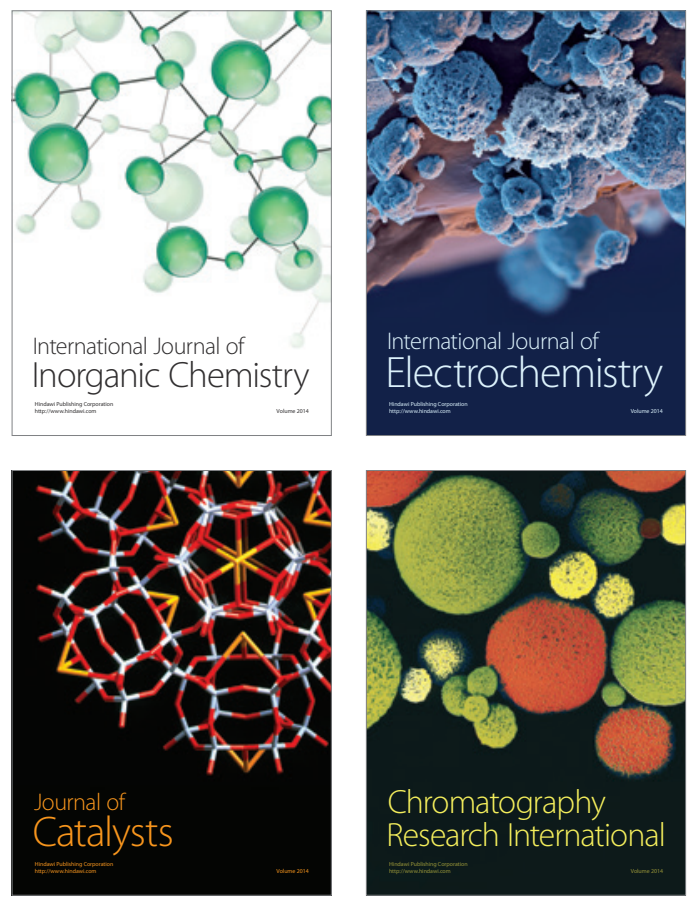
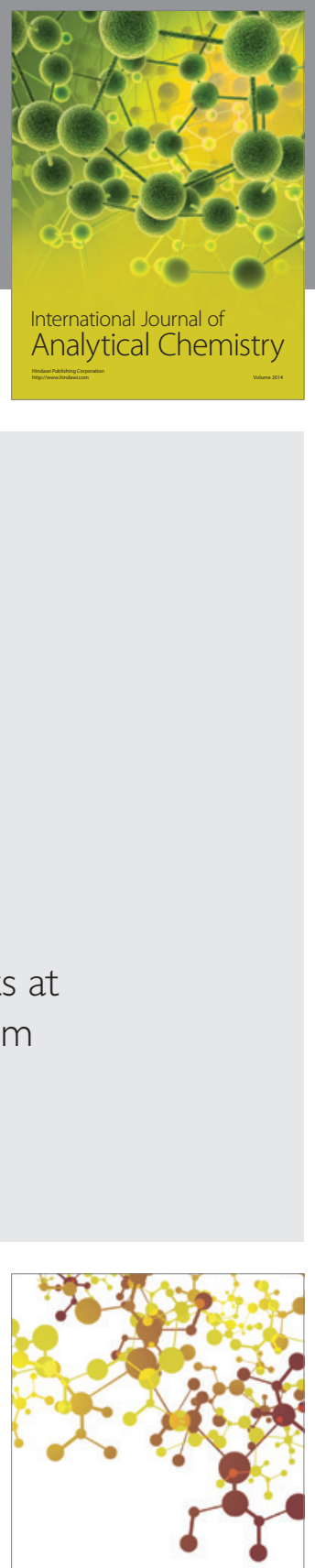

Journal of

Applied Chemistry
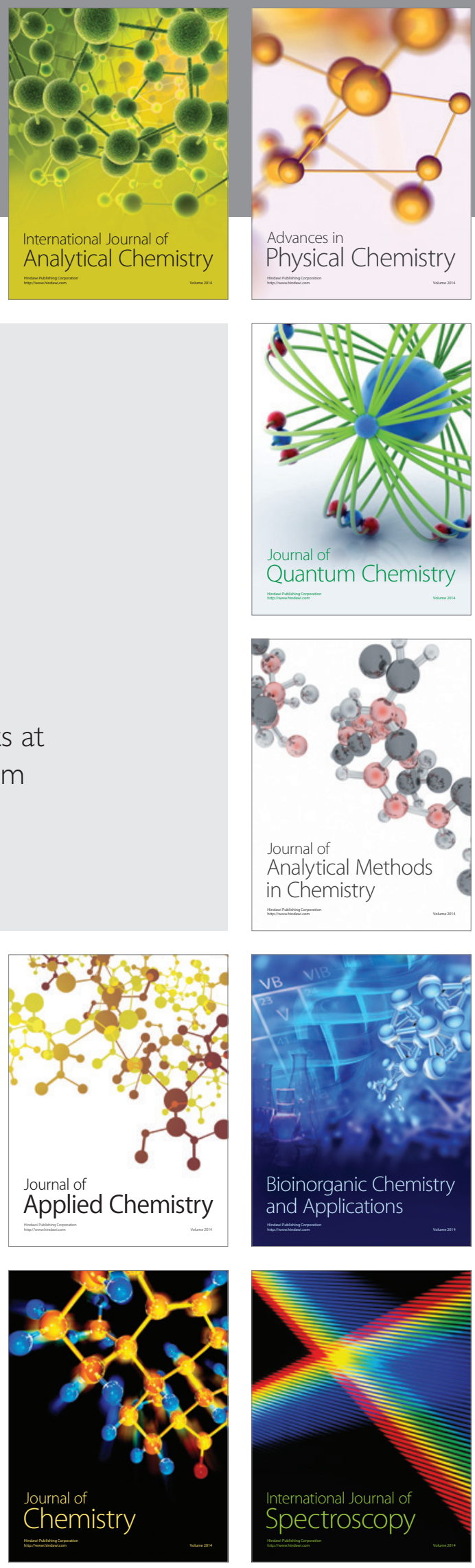